UDK 821.111(73=669)-31.09Cole T.

\title{
TEJU COLE'S NIGERIA AND THE OPEN CITIES OF NEW YORK AND BRUSSELS
}

\author{
Igor Maver \\ Dedicated to Chinua Achebe (1930-died 2013), the first \\ major African/Nigerian writer in English
}

\begin{abstract}
The novel Open City (2011) by the Nigerian-born and raised author Teju Cole is set in New York City, where he has lived since 1992. The narrator and protagonist of the book, the young Nigerian doctor Julius in is a veritable flâneur in the Big Apple, who is observing the rapidly changing multiethnic character of the city and meditating on (his) history and culture, identity and solitude, and the world beyond the United States, with which it is interconnected through the global history of violence and pain. He is juxtaposing the past and the present, the seemingly borderless open city of New York, Nigeria, and the various European locales, particularly Brussels. The novel, although set in the United States, is constantly interspersed with his recollections of his past experiences conditioned by his complex hybrid Nigerian-European-American identity.
\end{abstract}

Keywords: American literature, 9/11, diaspora, identity, Nigerian literature

That night I took the subway home, and instead of falling asleep immediately, I lay in bed, too tired to release myself from wakefulness, and I rehearshed in the dark the numerous incidents and sights I had encountered while roaming, sorting each encounter like a child playing with wooden blocks, trying to figure out which belonged where, which responded to which. Each neighborhood of the city appeared to be made of a different substance, each seemed to have a different air pressure, a different psychic weight: the bright lights and shuttered shops, the housing projects and luxury hotels, the fire escapes and city parks. My futile task of sorting went on until the forms began to morph into each other and assume abstract shapes unrelated to the real city; and only then did my hectic mind finally show some pity and still itself, only then did dreamless sleep arrive. (Open City, 6-7) 
Teju Cole's recent book Open City (Cole 2011) is an urban city novel about the open city of New York, although it is also as much about the 'open' city of Brussels, where Julius, the narrator of the book, finds the ethnic/multicultural openness of the latter more problematic: he spends a long vacation in Brussels, primarily in search of his German oma/grandmother on his mother's side, while he is an American-Nigerian resident of New York City. Historically, the official declaration and description of a city to be 'open' has been made by a warring side which was on the verge of defeat and surrender. This is what happened in Brussels in 1940 which the book does mention; in other cases, those making such a declaration were willing and able to fight on, but prefered that a particular city be spared. On the other hand, the author declares New York City 'open' in the context of accepting the inflow of many migrants from all over the world, a city that protects them from the vicissitudes of modern life, wars and suffering, a heaven-haven, a post-colonial metropolis that he perceives as such. On the other hand, surrender also seems to be in the focus here, for there are new migrants to NYC who give and take in order to adapt to the new environment: this is actually true of all the multi-layered and multi-ethnic world metropolises. An Audenesque suffering is, to his mind, the conditio sine qua non of the human condition. In fact, Cole speaks about violence, trauma, war in a new way, indirectly, describing not the external events but rather the consequences of suffering upon one's psyche, individual and collective memory. But NYC is not immune to violence either, the protagonist broods over Ground Zero, since the novel was written in the post-9/11 period. Julius's New York walkabouts represent the framework narrative of the text, featuring the travels and reminiscences inbetween, the Proustian flâneries of the narrator, the young doctor of psychiatry Julius, who is part American, part Nigerian and part German. The text moves freely between the present and the past on three continents; in addition to New York City and Brussels partly also Lagos in Nigeria, with the fictional protagonist, the hybrid and often alienated but nonetheless reliable narrator, in a desperate search of his identity, even if he is not consciously aware of that search.

This is not a typical book of fiction, a novel per se, with a weak narrative plot development, undoubtedly something of a drawback in the book, for it is, we can speculate, largely based on the narrator's/author's own experiences. He makes no particular effort to distinguish between the two as he moves freely between fiction and reality, his recollections of the past and travels. The style of writing of the book is smooth-flowing, grappling indeed, showing the author's great knowledge of art history, other literary texts, music and paintings. This symphonically-structured novel moves forward by leaps and retro-bounds effortlessly, with the sound of music, Wagner, Mozart and especially Gustav Mahler, stylistically chiselled, composed and tranquil, interspersed with frequent references to visual art. The text actually works as a musical piece, with Mahler opening and closing it fittingly by his musical 'death' piece, i.e. his Ninth Symphony (saying farewell). It moves by employing a counterpoint rhythm and fugue-like, structural techniques. The main framework of the book is the concept of the open global city, while the second one is Julius's hybrid identity and search for his ancestors, parents, memories swirling about the inner-city natural and and the various urban habitats of New York City.

It is true, however, that Cole deliberately provides an intellectual show-off and artistic refinement to the extent that one may even wonder whether the narrator Julius 
might be an intellectual poseur. One has to clearly distinguish between the author and the protagonist of the novel: Teju Cole, born to Nigerian parents in the USA and raised in Nigeria, from where he returned to New York during his late adolescence and where he now lives. If identity is a mix of inheritance, memory and pure fiction, then NYC with its many historical layers of urban history is the right palimpsestic site for its examination. The protagonist and first person narrator in Open City, on the other hand, has a double hybrid identity, being American, Nigerian and German. Given the fact that Teju Cole is also a photographer and a professional historian of early Netherlandish art, the book abounds in visual images and photographic realism, often presenting New York City from the slice-of-life angle.

The involuntary memory of a Proustian flâneur and modern urban spectator, in a clearly Romantic stance, as it results from the introductory epigraph above, characterizes Julius. As Charles Baudelaire defined the flâneur:

The crowd is his element, as the air is that of birds and water of fishes. His passion and his profession are to become one flesh with the crowd. For the perfect flâneur, for the passionate spectator, it is an immense joy to set up house in the heart of the multitude, amid the ebb and flow of movement, in the midst of the fugitive and the infinite. To be away from home and yet to feel oneself everywhere at home; to see the world, to be at the centre of the world, and yet to remain hidden from the world-impartial natures which the tongue can but clumsily define. (Baudelaire)

Open City is Teju Cole's debut novel, and it won the PEN/Hemingway Award, the New York City Book Award, and the Rosenthal Award of the American Academy of Arts and letters. The narrator Julius roams through the seemingly borderless open city metropolis of New York with it ever-changing migrant population, still haunted by the post-traumatic memory of 9/11. Cole had prior to Open City published a novella wih photographs about contemporary Lagos from the point of view of a diasporic Nigerian person returning home for a brief visit, Every Day is for the Thief, in 2007, which is partly connected to Open City. In this case, however, the Nigerian narrator returns from New York to Lagos to visit his friends and relatives, only to be disappointed at the violence and corruption he finds there, although he also has hope for a change. He is now working on a non-fictional book about Lagos, based on fait divers from everyday life he can gather from the internet and the papers: "The idea is not to show that Lagos, or Abuja, or Owerri, are worse than New York, or worse than Paris. Rather, it's a modest goal: to show that what happens in the rest of the world happens in Nigeria, too, with a little craziness all our own mixed in" (www.tejucole.com/small-fates/).

The novel opens with the description of Julius, who indulges in randomly walking about Manhattan. He watches the birds migrate as part of the natural migration process, as opposed to the »unnatural« migration of people into New York City. As an avid classical music listener, Julius often listens to musical fugues which he compares to the city's »incessant loudness, a shock after the day's focus and relative tranquility « (6). Julius first walks around the Upper West Side, then visits his old and ailing professor of English, Japanese-American Saito, for whom he has a deep respect and gratitude for introducing him to English literature during his two years at college 
before entering the Medical School. The professor talks to him about his hybrid identity of being a Japanese-American, especially during a concentration camp confinement for the Japanese during World War Two, which anticipates Julius's own identity search in the novel: »For me, in the forties, memorization was a helpful skill, and I called on it because I couldn't be sure I would see my books again, and anyway, there wasn't much to do at the camp. We were all confused about what was happening, we were American, had always thought ourselves so, and not Japanese« (13). The narrator's fascination for classical music is the fil rouge of the structural organisation of the book. Gustav Mahler opens and closes it, namely with his late instrumental-vocal symphony Das Lied von der Erde, and it is precisely his music that often transposes the narrator into a »reverie « (17). One day he ventures into Harlem to find »the brisk trade of sidewalk salesmen: the Senegalese cloth merchants, the young men selling bootleg DVDs, the Nation of Islam stalls. There were self-published books, dashikis, posters on black liberation, bundles of incense, vials of perfume and essential oils, djembe drumbs, and little tourist tchotchkes from Africa. One table displayed enlarged photographs of early-twentiethcentury lynchings of African-Americans « (18).

When Julius sees a cripple in the busy street dragging his broken leg behind him, he resorts to his Nigerian heritage and gets the impression that all the things he is seeing around himself are under the aegis of Obatala, the demiurge charged by Olodumare to create humans from clay. The Yoruba namely, he explains, believe that when drunk he made dwarfs, cripples, and those burdened by a debilitating illness. Moreover, he notes that from the Dutch colonization onwards native Americans in the area of New York have been completely wiped out (e.g. Cornelis Van Tienhoven, who was described in a recent history book The Monster of New Amsterdam). Julius compares Van Tienhoven to Pol Pot, Hitler and Stalin: he certainly sees violence and supression all over the world as having existed for centuries. The author of this particular book, a certain V., becomes Julius's patient and tells him: »There are almost no native Americans in New York City, and very few in all of the Northeast. It isn't right that people are not terrified by this because this is a terrifying thing that happened to a vast population. And it's not in the past, it is still with us today, at least, it is still with me« (27).

At the end of Chapter 2, Julius decides to watch a new film set in Africa. Few people attend. He is appalled to see that the director used music from Mali to represent Kenya and is annoyed and angry to conclude that »Africa was always waiting, a substrate for the white man's will, a backdrop for his activities. And so, sitting to experience this film, The Last King of Scotland, I was prepared to be angry again. I was primed to see a white man, a nobody in his own country, who thought, as usual, that the salvation of Africa was up to him. The king the title referred to was Idi Amin Dada, dictator of Uganda in the 1970s « (29). Walking about New York City seeing all its ethnic diversity, Julius suddenly (»on the uptown train «) starts to feel the need to see his German oma (grandmother), who might be in one of the nursing homes in Brussels, but he has no idea how to locate her: it is then that he decides to go for a long holiday of several weeks to Brussels. We learn how he and his mother had become estranged from each other when he was seventeen, just before his departure for the USA. Likewise, he thinks, his mother had grown estranged from her own mother, Julius's oma, and never returned to Germany. Julius in his hybrid Nigerian-German-American identity swirl 
thus reminisces about oma's visit to Nigeria and her tour of Yorubaland, where she came from her home residence in Belgium which she was living at then. Julius nurtures very fine thoughts for his grandmother and, as he is not sure whether she is still alive, he decides to go to Belgium, perhaps to find her or at least to walk in her footsteps. He believes she could be in a nursing home there, though he does not know where. The next day, wandering through the streets of NYC he has a flash-back recounting his meeting with a blind bard in Lagos when he was a child, somewhat reminiscent of himself and his grandmother:

Once, in a crowded market at Ojuelgba, sometime in the early eighties, I saw him.... He sang in a plaintive and high-pitched voice, in deep, proverbial Yoruba that was impossible for me to follow. Afterward, I imagined that I had seen something like an aura around him, a spiritual apartness that moved all his hearers to reach into their purses and put something in the bowl his assistant boy carried. (38)

The narrator of the book travels through the city by bus, subway, cab, or rather mostly walks all over the city and his visual memory is acute, always comparing the diverse architectural styles, for example Wall Street in Lower Manhattan, to the English gothic style. He steps into the Trinity Church just past Wall Street and Broadway to pray for an ailing friend. The Trinity Church, he elaborates on at length, has a significant place in American literature and culture. Julius quotes from the early New Amsterdam Dutch settler Antony de Hooges's writing, where he describes a certain white fish in the Hudson river and beached sperm whale. The whale had a symbolic importance for the Dutch. To see a whale and even more an albino whale in the area of the New Amsterdam settlement: since the beached whales in the Netherlands were immensely historically important (for example, the whale of Berckey near The Hague beached in 1598). It was some two hundred years later that Herman Melville was inspired by this legendary account. He was a parishioner of the Trinity Church and wrote his famous novel The Whale: Moby Dick on an albino Leviathan. The narrator slips his hand into the Hudson river and thinks about the passage of life, about eternity, how we ignore nature and are totally daily consumed by banal everyday questions. He is uncomfortable more than once when an African man tries to 'brother' him, as he is not in search of establishing a black brotherhood friendship at all cost. He passes by Ground Zero site and concludes that atrocity is historically nothing new, not to humans nor animals, except that in the modern world »it is uniquely well organized, carried out with pens, train carriages, ledgers, barbed wire, work camps, gas. And this late contribution, the absence of bodies. No bodies were visible, except the falling ones, on the day America's ticker stopped. Marketable stories of all kinds had thickened around the injured coast of our city, but the depiction of the dead bodies was forbidden. It would have been upsetting to have it otherwise. I moved on with the commuters through the pen« (58). The narrator also describes Groud Zero:

The perimeter marked out the massive construction site. I walked up to a second overpass, the one that once connected the World Financial Center to the buildings that stood on the site. Until that moment, I had been a lone 
walker, but people that began to troop out of the World Financial Center, men and women in dark suits including a group of young Japanese professionals who, tailed by the rapid stream of their conversation, hurried by me.... When I came up to the overpass, I was able to share their view: a long ramp that extended into the site, and the three or four tractors scattered around inside it that, dwarfed by the size of the pit, looked like toys. Just below street level, I saw the sudden metallic green of a subway train hurtling by, exposed to the elements where it crossed the work site, a livid vein drawn across the neck of 9/11. Beyond the site was the building I had seen earlier in the evening, the one wrapped in black netting, mysterious and severe as an obelisk. (57-8)

Julius also notes that before the erection of the Twin Towers of the World Trade Center in the 1960s various activities at various venues had taken place on the old Washington market, active piers, the fishwives, the Christian Syrian enclave established here in the late 1800s. He pays a visit, with his girl-friend Nadège, to an immigrant detention facility for undocumented migrants (Africans, Latinos, Eastern Europeans, Asians) and sees a plethora of new migrants who ended up there. He relates in some detail the life story of Saidu from Liberia, who made his way up to Tangier in Morocco and then Ceuta, the Spanish enclave, from where he manages to enter Spain, then Lisbon and finally illegally arrives to the USA.

Chapter Six is a flash-back into Julius's childhood and early adolescence, his attending the Nigerian Military School in Zaria, which was his father's wish. He remembers how he had no objection to going to Northern Nigeria, which he found »a desertified territory, with small trees and parched shrubs, might as well have been another continent, so different was it from the chaos of Lagos « (77), for him far away from his native Yorubaland up into the Hausa Caliphate. He writes about a deepening rift with his German mother originally from Magdeburg. His insecure hybrid identity is explicitly stated:

The name Julius linked me to another place and was, with my passport and my skin colour, one of the intensifiers of my sense of being different, of being set apart, in Nigeria. I had a Yoruba middle name, Olatubosun, which I never used. That name surprised me a little each time I saw in on my passport or birth certificate, like something that belonged to someone else but had been long held in my keeping. Being Julius in everyday life thus confirmed me in my not being fully Nigerian. (78)

He draws parallels between the Second World War and the German ancestry of his mother and the Nigerian military coup of 1976, marking also the untimely death of his Nigerian father. He saves money and borrows money to study in the USA, on his own terms.

Chapters Seven to Eleven are all set in Brussels, his long vacation there, designed particularly to come across his grandmother, even if only indirectly. Julius rents a private apartment from a girl called Mayken in the centre of Brussels and on the flight to Brussels meets Annette Mailotte, a retired doctor, who has been living in the US for a number of years, but who regularly comes to Brussels, where she keeps an apartment. 
He learns a lot from her about Belgium, from her point of view, of course, and why she had not stayed in Belgium professionally and academically: »She told me that she had done her training in Louvain. But you must be a Catholic to be a professor there, she said with a chuckle. Not so easy for an atheist like me: I've always been one, I'll always be one. Anyway, it's better than Université Libre de Bruxelles, where no one can achieve anything professionally without being a Mason« (89). Dr. Maillotte has a good friend in Brussels and invites Julius to have dinner with them during his long vacation in Brussels, Grégoire Empain - one of the grandsons of Baron Empain, an important name in Belgian history who had built Heliopolis in Egypt, where his palace still stands. Empain was a sucessful industrialist, who masterminded the Paris metro and was also amateur egyptologist, who had helped the Belgian government acquire some important Egyptian items for the Brussels museum. His host Mayken picks him up and on the way to the city presents a heap of stereotypes (»the French are lazy « 96) upon Julius, who does not have any idea: Flemish, Walloon? Julius had been twice before to Brussels, but only for a short time, on his way to America. He wants to amend the erroneous American views of this old capital:

It is easy to have the wrong idea about Brussels. One thinks of it as a techocrats' city, and because it was so central to the formation of the European Union, the assumption is that it is a new city, built, or at least expanded, expressly for that purpose. Brussels is old - a peculiar European oldness, which is manifested in stone - and that antiquity is present in most of its streets and neighborhoods. The houses, bridges, and cathedrals of Brussels had been spared the horrors visited on the low farmland and forests of Belgium, which had borne the brunt of the countless wars fought on the territory. Slaughter and destruction, ferocious to a degree rarely experienced in history, had taken place on the Somme, in Ypres, and before that, out at Waterloo. (97)

Julius is struck to find large numbers of people from Africa in Brussels, from Maghreb and the Congo, the latter of which surely had all to do with its colonial past in the Belgian Congo Free State controlled by the Belgian King Leopold II until the early 20th century and, from 1908, the Congo as the Belgian colony. Julius notes racial tensions and immigration discontent with many Belgians: »The country was in the grip of uncertainties - the sense of anomie was apparent even to a visitor « (100). He walks into the Parc du Cinquantenaire, feels dwarfed by the sheer size, and sees from afar tourists taking photos, silently. When he comes closer, he realizes they are speaking Chinese. He suddenly realizes he has to try to find his grandmother, but there is no Magdalena Müller in the phone book. Near his rented home he gradually enters into long conversations with Farouq, a Moroccan from Tétouan, who works in an internet café. He gets the feeling of rage and violent rhetoric on Farouq's side and anti-immigration feeling, on the other.

In a café in Grand Sablon he meets a young Czech woman and ends up having a one night stand with her. There is still no sign of his grandmother: he looks at old women huddled at tram stations, and hopes to see her there. He remembers the day they visited Olumo in Nigeria, and she had wordlessly massaged his shoulder. However, 
no sign of her whatsoever. Julius's encounters with Farouq and his Arab friends make him increasingly uneasy, with anger seething underneath the surface. In Chapter Ten he returns again to his adolescence spent in Lagos, but then suddenly realizes he is in Brussels. His much sought-after solitude in Brussels is interspersed with his encounters of various Africans: contrary to his initial belief that everybody in Belgium is from the Congo, he meets people from Mali, Rwanda, Sierra Leone, Liberia and the question significantly goes through his mind: »Who, among those present, I asked myself, had killed, or witnessed killing? «(139). Julius perceives life as a continuity and, only after it becomes the past, he feels, we are able to see its discontinuities. In trying to recover the submerged hybrid layers of his self, he confesses: »Nigeria was like that for me: mostly forgotten, except for those few things that I remembered with an outsize intensity. These were the things that had been solidified in my mind by reiteration, that recurred in dreams and daily thoughts: certain faces, certain conversations, which, taken as a group, represented a secure version of the past that I had been constructing since $1992 \ll(156)$.

In Chapter Thirteen the reader learns that upon the return to New York City from Brussels, his mind is vacant, he is »subject to a nervous condition « (161), when he is buying medicine in a Wall Street pharmacy. He finds some solace again in his compulsory »reverie« walks in the city. In this second part of the book he becomes a flâneur in Lower Manhattan. Every area he visits has an abundantly described historical context, the Chinese, the port of New York, etc. He walks all the way down the Bowery to the Lower East End, then away from the tourist crowds, to east Broadway, where he finds that everybody is Chinese, or can be taken for one. He finds the monument to Lin Zexu, an antinarcotics activist, a hero of the Opium wars, who was much hated by the British in impending their China drug traffic and who had been appointed commissioner in Guangzhou in 1839.

Near Morningside Park on the North West Side Julius is one night badly mugged, beaten and kicked by two very young adolescent African-American 'brothers', stealing his wallet and phone. This makes him think differently about race: race does not discriminate in crime, he concludes looking at his painfully disfigured jaw. Still, he explores the black racial history of New York City, finding an African burial ground, which is mostly covered by new buildings, not too far from City Hall Park. He writes about slavery in Manhattan and how it has been covered by the layers of the past in the palimpsest the city is today. After the rape of his girlfriend Moji in the past, he experiences something of a shock seeing her again. He manages to suppress this deed yet again into his subconsciousness, just as his connection/identification with Africa, which is, despite his evasive attitude, constantly there in his life and innermost thoughts through a negative presence. He remains hopelessly deracinated. Julius talks a lot about death and burial at the end of the novel, the death of his father, his grandfather, that of his beloved composer, Mahler in 1911, referring also to the famous El Greco painting from Toledo, Spain, Burial of the Count of Orgaz. The final 21st Chapter ends with a description of his first full day in the psychiatric practice on the Bowery with a senior partner of his. Mahler's music fittingly ends the narrator's musings on death: he goes to hear Mahler's vocal-symphonic piece Das Lied von der Erde at the Carnegie Hall, and then his Ninth Symphony, commenting on both: »The overwhelming impression they 
give is of light: the light of a passionate hunger for life, the light of a sorrowful mind contemplating death's implacable approach « (250). He ends his city journey symbolically with a boat trip to the Statue of Liberty on Liberty Island and feels sorry for the handful of wrens that have been disoriented and have, paradoxically, found suffering and death in it - like humans - searching for liberty.

Teju Cole's first novel Open City has received positive reviews from critics: they have compared him to the writing of Joseph O'Neill and Zadie Smith (The New Yorker), his honesty has also been noted (The New York Times). The buried layers of the past underneath the skyline of NYC today is what he aims at discovering, so that the book is a meditation on the suffering in history, identity quest and, above all solitude, that the narrator does not wish to break. At the same time he hopes to unveil the palimpsest of his own self, which he is not fully capable of coming to terms with. The Big Apple flâneur, Julius, is constantly watching the city and its bird life: he finds the city globally interconnected with the rest of the world through pain and suffering. NYC expresses and caters well to his hybrid identity, a veritable palimpsest of African-American memory. He grapples with his partly Yoruba identity and never feels fully Nigerian, and does not trust his passport which says he is Nigerian, for he is as much American and German. The »new migrants « to the USA and New York City are his main points of ineterest, from Africa, Asia and the Caribbean region in particular. Talking to the angry migrants in Brussels makes him reflect upon the American as well as European identity crisis, especially after 9/11. New York is shown as a metacity (according to the well-known Dutch architect Winy Maas), which is not defined by topographical facts or prescribed ideologies, nor representation or context but rather by the people inhabiting it. The book nonetheless inspires calmness, inner peace, a Wordsworthian connection of the onlooker with nature, so his position is somewhat Romantic, isolated against the crowds, trying to find a connection with nature and with his own self: Julius is ultimately unable to do either of these two. On the other hand, Julius, who is increasingly turning from a reliable into an unreliable narrator, especially when we learn about his committing rape, is all along very distant and cannot seem to be able to connect with people around him. This is particularly true of women, with whom he has troubled relationships in one way or another (his mother, Moji, Nadège). The text ofen reads as a musical score that adds to its appeal. Paradoxically, the hassle of the great megalopolis enables the narrator to find at least an imaginary identity and mental stability, inner peace and solitude, which effectively rubs off onto the reader as well.

University of Ljubljana, Slovenia

\section{WORKS CITED}

Baudelaire, Charles. »The Painter of Modern Life«. New York: Da Capo Press, 1964. Orig. published in Le Figaro, in 1863.

Cole, Teju. Open City. London: Faber \& Faber, 2011. . Every Day is for the Thief. Abuja, Nigeria: Cassava Republic press, 2007. 